\section{Effect of interactive post-reading tasks on reading comprehension of Iranian young adults pre-intermediate EFL learners}

Salavati, Atena

Islamic Azad University of Najafabad, Iran (atenasalavati84@ gmail.com)

Tabatabaei, Omid $\square$

Islamic Azad University of Najafabad, Iran (tabatabaeiomid@yahoo.com)

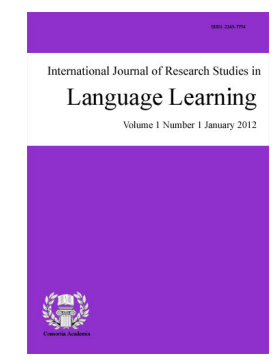

ISSN: $2243-7754$ Online ISSN: 2243-7762

OPEN ACCESS

\title{
Abstract
}

This study aimed at investigating the effects of role-playing and designing a poster as post-reading activities on Iranian teenagers EFL learners' reading comprehension. To this end, 90 male pre-intermediate EFL learners participated in this study. The participants were divided randomly into equal groups of role-play, poster, and control. Post-reading activities were used for the experimental groups and the control group did not receive any post-reading activities. All groups sat for the pretest and posttest before and after a 20 -session treatment. The results indicated that the experimental group participants outperformed those of the control group on the posttest and there was a significant difference between them. There was not a significant difference between the experimental groups; however, the scores of the role-play group were higher than the poster group. The findings of the study offer some practical implications for curriculum development and teaching methodology.

Keywords: post-reading activities; poster making; reading comprehension; role playing; interactive activities 


\section{Effect of interactive post-reading tasks on reading comprehension of Iranian young adults pre-intermediate EFL learners}

\section{Introduction}

Reading comprehension is the amount of understanding of a piece of writing. This understanding comes from the interaction between the written words and activating the knowledge outside the text/message (Rayner, Foorman, Perfetti, Pesetsky, \& Seidenberg, 2001). Proficient reading is the ability to understand words rapidly and effortlessly (Adams, 1994). According to Richards and Schmidt (2010), there are different types of reading comprehension based on the reader's purpose: (a) Literal comprehension, which is reading to understand, remember, or elicit the information clearly included in a passage, (b) Inferential comprehension which is reading to discover information which is not clearly stated in a passage, (c) Critical or evaluative comprehension which is reading to compare information in a passage with the reader's own knowledge and values, and (d) Appreciative comprehension which is reading to obtain a valued response from a passage.

Reading activities are divided to pre-reading, during-reading, and post-reading activities. Pre-reading activities let students think about what they already know about a given topic and predict what they will read or hear (Brassell \& Rasinski, 2008). According to Ajideh (2006), some pre-reading activities merely contain questions to which the reader should find answers from the text. Other pre-reading tasks focus solely on preparing the reader for likely linguistic difficulties in a text and, more recently, attention has shifted to cultural or conceptual difficulties. During-reading activities are done simultaneously while reading the text by the students. They are designed to guide students to a more active approach to reading, and to encourage them to check their comprehension (Alessi \& Dwyer, 2008). Post-reading or after-reading activities are active reading strategies applied after reading a text. Post-reading activities are constituted of reviewing assignments or activities that will extend the official completion, but will attach new concepts and sharpen opinions (Wolfe, 2015).

"Role playing is language teaching drama-like classroom activities in which students take the roles of different participants in a situation and act out what might typically happen in that situation" (Richards \& Schmidt, 2010, p. 501). Role-play, simulation, and drama are useful language learning tools (Schellin, 2006). According to Schellin (2006), simulation is longer than role-play, and students do not change their own identities and they do not play roles. In role-play, on the other hand, students take a role and play a part in a particular situation. In drama, students are expected to act out exactly what is written in a script.

A poster is any piece of printed-paper, which is designed to be attached to a wall or vertical surface (Gosling, 2012). According to Max (2002), posters have been displayed for more than two hundred years in public places in all over the world in order to attract people's attention and enticing them to attend specific events. According to Aduradola and Akeredolu-Ale (2013), posters involve descriptive pictures or photographs; artwork and printed work used as communicative advertisements presented in brief forms for public display.

\subsection{Research Questions}

The present study was aimed at finding suitable answers to the following research questions:

$>$ Does Role-play as a post-reading activity have any significant effect on the improvement of Iranian pre-intermediate EFL learners' reading comprehension?

$>\quad$ Does designing posters as post-reading activity have any significant effect on the improvement of Iranian pre-intermediate EFL learners' reading comprehension? 
$>\quad$ Which task (Role-playing or designing a poster) is more effective on the improvement of Iranian pre-intermediate EFL learners' reading comprehension?

\subsection{Research Hypotheses}

This study was conducted based on the following research hypotheses:

$>\quad$ Role-playing task as a post-reading activity does not have any significant effect on the improvement of Iranian pre-intermediate EFL learners' reading comprehension.

$>\quad$ Designing a poster as a post-reading activity does not have any significant effect on the improvement of Iranian pre-intermediate EFL learners' reading comprehension.

\section{Review of Literature}

According to Yusuf (2015), Interactive activities are activities that expose learners to high level of s participation. Various forms of group activities range from discussion to retelling. The teacher directs students to operate different learning tasks at various levels of interaction. Based on the meaning, students learn about the mental processes involved in triggering ideas and making relations between known and unknown ideas. This strategy makes students to understand that three different types of meaning can be created during reading-literal, inferential, and personal. They develop understanding that reader's previous knowledge plays an important role in making meaning and that several meaning exists around a text.

Yusuf (2015) investigated the effect of interactive activities on students' performance in reading comprehension. Two secondary schools were used for the study. Eighty homogenized senior secondary school students were selected for the study, i.e. 40 students from each school. The two schools were located far apart i.e. government secondary school Doka, Kaduna North, Government secondary school, Makara in Kaduna South. Two reading comprehensions were administered to students. Eight passages were cautiously selected from the "senior English project for secondary schools" textbook I. The passages were chosen because they were interesting in nature, related to subject matter, and relevant to both genders. The passages were educative and informative. A pretest was administered to both control and experimental groups to make sure about their homogeneity. The experimental group was taught reading comprehension via interactive activities for eight weeks while the control group had their normal reading comprehension lessons taught by their teacher. A post-test on the passages that were taught was administered to the two groups after eight weeks of teaching.

The results showed that interactive activities have a significant effect on students' performance on reading comprehension. The findings also revealed that interactive activities are beneficial for understanding and comprehending texts. It also assists teacher in seeing how students' personal thought processes are working with the information obtained from texts. It is highly recommended that teachers use interactive activities to improve students' reading comprehension. The activities such as turn on the meaning by involving students in determined strategic conversations provide students with many opportunities to interact with text, teacher, and classmates. Endorsing conversation by turning on meaning applying light bulbs, multiple activities, and experiences using an assortment of ways of communications such as teacher-student, student-teacher, student-students could surge their use of language along with improve reading fluency. The goal of reading instruction should be to help learners interact with text meaningfully. Students should be guided to be independent readers by being able to gain meaning from text and make sense of the content of what is read.

Based on Atay and Kurt (2006), As language learning consists of the achievement of thousands of words, teachers similar to learners would like to know how vocabulary learning can be promoted, particularly in EFL contexts where learners where most learners do not develop strong mental lexicons, even though they study English formally for years. Research reveals that reading is important but not enough for second-language vocabulary learning, and that it should be accompanied by post-reading activities to augment students' 
Salavati, A., \& Tabatabaei, O.

vocabulary knowledge. Therefore, they investigated the effects of two types of post-reading activities: discrete written tasks on their own and a combination of written tasks along with interactive tasks on the vocabulary acquisition of young learners in an EFL context. The participants in this study were 62 Grade 6 students in two classes in a public school in Istanbul, Turkey. The two classes were compared by the students' first-term English achievement test scores, and the $t$-test applied to the achievement scores did not show any difference between the groups. Hence, it can be declared that the students were randomly assigned to control and experimental conditions, with 32 and 30 students respectively, in which are the participants were at the same level of proficiency in English. The students were all native speakers of Turkish with an average age of 11. They were all from low-income families, none of them had ever been to an English-speaking country, and all had very few opportunities to use English for communicative purposes outside the classroom. They all had English in Grades 4 and 5 for two hours a week and as Grade 6 students they had English for four hours a week.

The findings of the study have implications for young-learner English instruction, especially in the EFL contexts where teaching and learning conditions are not perfect. The findings of their study revealed that interactive tasks as post-reading activities are an effective way of improving young EFL learners' vocabulary knowledge. This type of post-reading task can be employed in young-learner classes as another possibility to traditional discrete written vocabulary tasks. Additionally, observations performed during the study showed that interactive tasks were much more interesting to the needs and interests of young learners than written vocabulary exercises. In this respect, English teachers who work in the primary schools should be provided with in-service programs on the instruction of language teaching in primary education, and this training should be extensive and continuing.

Role-playing methods helps students discover their social worlds and to resolve daily life problems created by themselves and the society. Although the risk-taking is common in creativeness, it enables students to efficiently contrast problem-solving methods by role-playing a situation several times from miscellaneous viewpoints. In a more serious and personal way than other teaching-learning methodologies, it allows students to develop an understanding of others' point of view. It inspires students to work with others in exploring situations and developing useful solutions. It offers a creative way through which feelings can be expressed. Role playing simulation simplifies the improvement of language skills, and simulation creates a safe milieu which encourages authentic communication and active involvement. Students involve in real communication when playing their role and are so captivated in the activity that they forget about their doubts about using language incorrectly. It is classroom activities in which students take the roles of different participants in a situation and act it out what might normally occur in that situation (Richards \& Rodgers, 2014). The students are supposed to be capable of expressing their arguments, ideas, and even self-existences through certain roles in which the speaking skill is explored. The teachers however should pay attention to some points in planning the activities, because not all students feel comfortable to speak or even to imagine to be someone else.

Students also receive feedback on whether or not they have effectively communicated. Role-taking (role-playing) is also adaptable in its application in education that it will work for all characters and under all teaching conditions. Students can learn the language more easily by applying role-play. Furthermore, language has relationship with the culture of the people using it. One who learns a language actually learns the culture. Consistent with this theory, it can lead the students to say something used in daily activities in English and the situations when the expression should be said. Moreover, it is a good technique of practicing pronunciation and intonation since emotional features can affect the speakers. Therefore, it will encourage students to learn speaking actively.

Bibi, Majoka, Mahmood, and Tariq (2015) compared the effectiveness of role-play method with traditional teaching method. The participants were grouped in three categories i.e. high achiever, average achiever, and low achiever. Then effect of role-play was evaluated on each level of students. To see the effect of anything manipulation is necessary to measure impact level, therefore, an experimental study was designed and pre-test post-test experimental design was used. Eighty students were taken as sample of this study which were further 
assigned randomly to experimental and control groups. Experimental group was taught through role-play method while control group was taught by conventional method. Both groups were given the same pre-test and post-test which were achievement tests. The collected data was analyzed to measure the designed hypotheses.

The results showed that there was significant difference between the mean post-test scores of high achievers of experimental group and control group on post-test in all three domains i.e. knowledge, comprehension and application. Almost similar results were acquired in average achiever students and low achiever students. Therefore, they concluded that role-play method had equal effects for all levels of students. This method was better for all three categories of students (high achiever, average achiever and low achiever).

\section{Methodology}

\subsection{Participants}

The participants in this study were 90 EFL learners who were studying English as a foreign language at pre-intermediate level in three language institutes in Shahin Shahr and Isfahan. All participants were male learners and their ages ranged from 12 to 17. Oxford Placement Test (OPT) was run in order to determine the proficiency level of the participants and to make sure that all of them were at pre-intermediate level. After that, the participants were randomly divided into three equal groups, which each group consisted of 30 learners. There were one control and two experimental groups in this study. In the control group, there was no post-reading activity and reading was taught traditionally. The experimental groups received two different types of post-reading activities as treatment. One of the experimental groups received role-playing as the post-reading activity and the other group received designing a poster as the post-reading activity.

\subsection{Instruments}

Three types of instruments were used for conducting the current study. The instruments were Oxford Placement Test (OPT), the pretest, and the posttest.

$\boldsymbol{O P T}$ - The first instrument that was used in this study was the Oxford Placement Test (OPT). The OPT provides reliable and efficient means of placing students at the start of a course for teachers (Allan, 2004). According to Allan (2004), the tests have been calibrated against the levels system provided by the Common European Framework of Reference for Languages: Learning, Teaching, Assessment (commonly known as the $\mathrm{CEF}$ ), which has been adopted by the Association of Language Testers in Europe (ALTE) as well as by governments and major institutions, including exam boards, throughout Europe.

Pretest - In order to estimate the participants' reading comprehension ability, a pretest was designed by the researcher and conducted to the participants before the course. The scores of the pretest were collected to be compared with the scores of the posttest to determine the improvement of the participants after completing the course. The test consisted of four readings suitable for the students based on their level of proficiency and contained 20 multiple-choice questions (five questions for each text) from the readings that the participants had to read the texts carefully and answer the questions. Furthermore, to evaluate the reliability of the test, it was piloted to 10 of the participants before starting the course and the scores were gathered. After collecting the scores, the KR-21 formula was used for evaluating the reliability $(r=0.75)$. To determine the validity of the test, three experts who had Ph.D. degrees in TEFL were consulted and asked to express their opinions about the text and the questions.

Posttest - A posttest was designed by the researcher and used after completing the course to estimate how much the participants have improved in reading comprehension. To this end, the test was conducted to all participants and their scores were compared with the scores of the pretest. The posttest was similar to the pretest in nature and different in appearance. It means it also contained four texts and 20 multiple-choice questions with 
Salavati, A., \& Tabatabaei, O.

the same level of difficulty. Since the pretest and posttest had similar features, the same method was used for calculating its reliability and validity. The test was piloted to 10 of the participants and the reliability of the scores was evaluated by KR-21 formula. The validity of the test was evaluated the same as the pretest.

\subsection{Material}

Select readings pre-intermediate level book was used in the study as the material. This book is written by Linda Lee and Erik Gundersen and published by Oxford University Press in 2001. This book contains readings for pre-intermediate students of English and the readings address a wide range of exciting topics that are suitable for EFL and ESL learners (Lee \& Gundersen, 2001).

\subsection{Procedure}

In the first step OPT was used to determine the level of the participants and to make sure that all of them were pre-intermediate learners. After determining the level of the participants, they were divided randomly into three equal groups which each group contained 30 learners. These three groups formed one control group and two experimental groups. All participants were studying an English learning course containing 20 sessions and there was a reading part at the end of each session. In the control group, there were not any post-reading activities and the reading process was done traditionally. For experimental groups, there were two kinds of post-reading activities named role-playing and designing a poster. Role-playing was used for one of the experimental groups and designing a poster was used for the other experimental group as post-reading activities.

In the role-play group, participants cooperated with each other to retell the text by playing different roles. Each participant played a role to express what he understood from the reading. The participants did not need to memorize the exact words and sentences of the reading; rather they were encouraged to use their own words. In the poster class, participants worked with each other to make a poster for each text. They used suitable pictures in their posters and captions that were related to the pictures. Similar to the previous group, participants were encouraged to use their own words, not the words in the book.

In the first session of the course, the participants' reading comprehension was tested by OPT. After completing the course, all participants were tested in order to find out how much they improved in reading comprehension and if there was a significant difference among groups. The readings that exist in the aforementioned book were used as pretest and posttest instruments.

\section{Results}

\subsection{Results of $O P T$}

In order to ascertain the learners in the three groups were homogeneous in terms of their overall language proficiency, their OPT scores were compared using a one-way ANOVA. The following table shows the results of the test.

\section{Table 1}

Descriptive Statistics Results of Comparing the Mean Scores of the three groups on the OPT

\begin{tabular}{|c|c|c|c|c|c|c|c|c|}
\hline & \multirow{2}{*}{$N$} & \multirow{2}{*}{ Mean } & \multirow{2}{*}{$S D$} & \multirow{2}{*}{ Std. Error } & \multicolumn{2}{|c|}{ 95\% Confidence Interval for Mean } & \multirow{2}{*}{ Min } & \multirow{2}{*}{$\operatorname{Max}$} \\
\hline & & & & & Lower Bound & Upper Bound & & \\
\hline Control & 30 & 37.53 & 1.63 & 0.29 & 36.92 & 38.14 & 35 & 40 \\
\hline Poster & 30 & 37.43 & 1.81 & 0.33 & 36.76 & 38.11 & 35 & 40 \\
\hline Role-play & 30 & 37.03 & 1.69 & 0.30 & 36.40 & 37.66 & 35 & 40 \\
\hline Total & 90 & 37.33 & 1.70 & 0.18 & 36.98 & 37.69 & 35 & 40 \\
\hline
\end{tabular}

As Table1 shows the mean scores of the control group $(\mathrm{CG})(M=37.53)$, poster group $(\mathrm{PG})(M=37.43)$, 
Effect of interactive post-reading tasks on reading comprehension of young adults pre-intermediate EFL learners and role-play group $(\mathrm{RG})(M=37.03)$ were not considerably different and it can be noted that they were homogeneous since their mean scores were almost the same. To figure out whether the differences among these mean scores were significant or not, the results were compared by One-way ANOVA. The following table indicates the results of One-way ANOVA.

Table 2

Results of One-Way ANOVA for Comparing the Mean Scores of the three Groups on the OPT

\begin{tabular}{lccccc}
\hline & Sum of Squares & $d f$ & Mean Square & $F$ & Sig. \\
\hline Between Groups & 4.20 & 2 & 2.10 & 0.71 & 0.492 \\
Within Groups & 255.80 & 87 & 2.94 & & \\
Total & 260.00 & 89 & & & \\
\hline
\end{tabular}

As is displayed in Table 2, there was not a statistically significant difference in the OPT scores for CG $(M=$ 37.53, $S D=1.63)$, PG $(M=37.43, S D=1.81)$, and RG $(M=37.03, S D=1.69)$ because the $p$ value under the $S i g$. column was greater than the specified level of significance (i.e. $.492>.05$ ), indicating that the three groups did not significantly differ in terms of their overall language proficiency and thus were homogeneous.

\subsection{Addressing Research Question One}

The first research question was "Does Role-play as a post-reading activity have any significant effect on the improvement of Iranian pre-intermediate EFL learners' reading comprehension?" To this end, an Independent-samples t-test was conducted to compare the CG and RG to figure out if there was any significant difference between the mean scores of the groups. The following table represent the results of the tests.

Table 3

Results of Descriptive Statistics for Comparing CG and RG on the Posttest

\begin{tabular}{lccccc}
\hline & Groups & $N$ & Mean & SD & Std. Error Mean \\
\hline Scores & Control & 30 & 15.30 & 1.67 & 0.30 \\
& Role Play & 30 & 18.13 & 0.83 & 0.17 \\
\hline
\end{tabular}

Table 3 shows the number of participants in each group, along with their mean scores, standard deviations, minimum scores, and maximum scores. The two mean scores appeared to be very different and the mean score of the RG $(M=18.13)$ was greater than the mean score of the CG $(M=15.30)$. However, to ascertain this was the case, independent-samples $T$ test table was consulted. According to the T-test results, there was a significant difference between the $\mathrm{CG}(M=15.30, S D=1.71)$ and the $\mathrm{RG}(M=18.13, S D=.84)$ since the $p$ value was lower than $.05(p<.001)$. It means the RG was significantly better than CG.

\subsection{Addressing Research Question Two}

The second research question was "Does designing a poster as a post-reading activity have any significant effect on the improvement of Iranian pre-intermediate EFL learners' reading comprehension?" To this end, an Independent-samples t-test was conducted to compare the CG and PG to figure out if there was any significant difference between the mean scores of the groups. The following table represent the results of the tests.

\section{Table 4}

Results of Descriptive Statistics for Comparing CG and PG on the Posttest

\begin{tabular}{lccccc}
\hline & Groups & $N$ & Mean & SD & Std. Error Mean \\
\hline \multirow{2}{*}{ Scores } & Control & 30 & 15.30 & 1.67 & .30 \\
& Role Play & 30 & 17.71 & 1.15 & .21 \\
\hline
\end{tabular}

Table 4 shows the number of participants in each group, along with their mean scores, standard deviations, minimum scores, and maximum scores. The two mean scores appeared to be very different and the mean score 
Salavati, A., \& Tabatabaei, O.

of the RG $(M=17.71)$ was greater than the mean score of the CG $(M=15.30)$. However, to ascertain this was the case, independent-samples $t$ test table was consulted. According to the T-test results, there was a significant difference between the CG $(M=15.30, S D=1.68)$ and the RG $(M=17.71, S D=1.16)$ since the $p$ value was lower than $.05(p<.001)$. It means the RG was significantly better than $\mathrm{CG}$.

\subsection{Addressing Research Question Three}

The third research question was "Which task (Role-playing or designing a poster) is more effective on the improvement of Iranian pre-intermediate EFL learners' reading comprehension?" To answer this question One-Way ANOVA was conducted to make comparisons among the three groups and the LSD test was run as post-hoc to figure out how these groups are different from one another. The results of the analyses are shown in the following tables.

Table 5

Results of the Descriptive Statistics of the three Groups

\begin{tabular}{|c|c|c|c|c|c|c|c|c|}
\hline & \multirow{2}{*}{$N$} & \multirow{2}{*}{ Mean } & \multirow{2}{*}{$S D$} & \multirow{2}{*}{ Std. Error } & \multicolumn{2}{|c|}{ 95\% Confidence Interval for Mean } & \multirow{2}{*}{ Min. } & \multirow{2}{*}{ Max. } \\
\hline & & & & & Lower Bound & Upper Bound & & \\
\hline Control & 30 & 15.30 & 1.67 & .30 & 14.67 & 15.93 & 12 & 19 \\
\hline Poster & 30 & 17.71 & 1.15 & .21 & 17.28 & 18.14 & 15 & 20 \\
\hline Role Play & 30 & 18.13 & 0.83 & .15 & 17.81 & 18.44 & 17 & 20 \\
\hline Total & 90 & 17.05 & 1.77 & .18 & 16.67 & 17.42 & 12 & 20 \\
\hline
\end{tabular}

The table indicates that the participants in the RG had the best performance among the groups $(M=18.13$, $S D=.84)$. To make sure if this difference was significant or not One-Way ANOVA was conducted. The results are shown in the following table.

Table 6

Results of One-Way ANOVA for Comparing among Groups

\begin{tabular}{lccccc}
\hline & Sum of Squares & $d f$ & Mean Square & $F$ & Sig. \\
\hline Between Groups & 139.65 & 2 & 69.82 & 43.08 & .000 \\
Within Groups & 141.00 & 87 & 1.62 & & \\
Total & 280.65 & 89 & & & \\
\hline
\end{tabular}

Table 6 indicates that there were significant differences among the three groups of the study because the $p$ value was smaller than $.05, p<.001$. To understand precisely what groups were significantly different in comparison with other groups, the LSD test was used as the post-hoc and its results are shown in Table 7.

Table 7

Results of LSD Test for Comparing among Groups

\begin{tabular}{llccccc}
\hline \multirow{2}{*}{ (I) Groups } & \multirow{2}{*}{ (J) Groups } & $\begin{array}{c}\text { Mean Difference } \\
\text { Control }\end{array}$ & St-J) & Std. Error & Sig. & \multicolumn{2}{c}{ 95\% Confidence Interval } \\
\cline { 6 - 7 } & Poster & $-2.41^{*}$ & .32 & .00 & -3.06 & -1.76 \\
\multirow{2}{*}{ Poster } & Role Play & $-2.82^{*}$ & .32 & .00 & -3.48 & -2.17 \\
& Control & $2.41^{*}$ & .32 & .00 & 1.76 & 3.06 \\
\multirow{2}{*}{ Role Play } & Role Play & -.41 & .32 & .20 & -1.07 & 0.24 \\
& Control & $2.82^{*}$ & .32 & .00 & 2.17 & 3.48 \\
& Poster & .41 & .32 & .20 & -0.24 & 1.07 \\
\hline
\end{tabular}

Note. ${ }^{*}$ The mean difference is significant at the 0.05 level.

The results that are shown in the table indicate that there were significant differences between the CG and PG $(p<.001)$ and the CG and RG $(p<.001)$ while there was not a significant difference between RG and PG ( $p$ $=.329$ ). These results indicate that applying both of these methods say, designing a poster and role-playing, as post reading activities has positive effects on improving EFL learners' reading comprehension. 


\section{Discussion and Conclusion}

According to Blanter (2009), it is better to use different learning techniques in the classroom to enhance the degree of learning and grasp of the new materials. Method of teaching which involves information transfer through action and participation is considered best for understanding. There has been much emphasis on the participation and creating community in the classroom, because it became joint adventure of teachers as well as students. Role-playing method helps students discover their social worlds and resolve daily life problems created by themselves and the society. Role play allows students to develop an understanding of others' point of view. It encourages students to work with others in analyzing situations and developing practical solutions. It presents a productive channel through which feelings can be expressed. Role playing simulation facilitates the development of language skills, and simulation creates a safe environment which encourages genuine communication and active involvement. Students are engaged in real communication when playing their role and are so captivated in the activity that they forget about their doubts about using language wrongly. It is classroom activities in which students take the roles of different participants in a situation and act it out what might typically happen in that situation (Richard \& Rodgers, 2014).

Bibi et al. (2015) compared the effectiveness of role play method with traditional teaching method. In this study students were categorized in three categories i.e. high achiever, average achiever and low achiever. Then impact of role play is measured on each level student. An experimental study was designed and pre-test post-test experimental design was used. Eighty students were taken as sample of this study which were further assigned as experiential and control group through random assignment. Experimental group was taught through role play method while control group was taught through traditional method. The results showed that there was significant difference between the mean posttest scores of high achievers of experimental group and control group on posttest in all three domains i.e. knowledge, comprehension and application. Almost similar results are found in average achiever students and low achiever students. Therefore, it could be concluded that role play method was equally effective for all levels of students.

The Results of the study were parallel with the findings reported by Kodotchigova (2001), Tarpey (2007), and Gorjian, Moosavinia, and Jabripour (2010).

Simpson (2013) defined posters as tools that can be used in a number of ways to overcome challenges and problems in the EFL classroom; the particular way they are used will depend on the teacher's experience and the students' needs. They are useful due to the following reasons: (a) Posters facilitate oral practice: Using posters at timely junctures during class acts as a great energizer for students, letting them know that it's time to switch to English. (b) Posters encourage authentic communication: Posters can serve as a springboard to authentic and creative language use. By taking advantage of students' knowledge in the topics we've studied that day, the poster acts as a way of getting the learners to express that content in their own way. (c) Posters augment self-confidence: As teachers, we should always aim to foster safe environments that encourage students to take risks. Dörnyei and Ushioda (2013) stress the notion of a secure environment as being fundamental to L2 learner motivation. In this sense, posters are non-threatening because teachers and students have time to develop the final product together, yet with the teacher acting solely as 'consultant'. Learners know they can count on us to oversee grammatically correct sentences in the written form, which allows for a degree of risk taking in the oral delivery of the finished product. (d) Posters accommodate a variety of learning style: the students who are the least engaged in the previous lessons suddenly find their place in the classroom during the poster session. As students hold, write on, engage with, and generally create the posters, they interact with the environment and are visually stimulated. (e) Posters foster learner autonomy: Posters really seem to enable students to take a greater role in their learning because they can make choices about which information to include and even how to work with their classmates. Such actions are uncommon in a teacher-dominated class and this handing over of control empowers learners and fosters their autonomy (Simpson, 2013).

According to Atay and Kurt (2006), reading is important but not sufficient for second-language vocabulary 
Salavati, A., \& Tabatabaei, O.

learning, and that it should be supplemented by post-reading activities to enhance students' vocabulary knowledge. This study investigates the effects of two types of post-reading activities: discrete written tasks on their own and a combination of written tasks along with interactive tasks on the vocabulary acquisition of young learners in an EFL setting. The participants in this study were 62 Grade 6 students in two classes in a public school in Istanbul, Turkey. The two classes were compared in students' first-term English achievement test scores, and the $t$-test applied to the achievement scores did not show any difference between the groups. Thus, it was concluded that the groups, randomly assigned to control and experimental conditions, with 32 and 30 students respectively, were similar in their English proficiency. The students were all native speakers of Turkish with an average age of 11 . The findings of the present study have revealed that interactive tasks as post-reading activities are an effective way of enhancing L2 vocabulary knowledge of young learners. This type of post-reading task can be carried out in young-learner classes as an alternative to traditional discrete written vocabulary tasks.

The results of the study are also in line with those implemented by Gold and Gibson (2001), Al-Mansour and Al-Shorman (2011), and Kowsary (2013).

Previous research has paid almost little attention to the merits of employing post reading activities to enhance reading comprehension ability of EFL learners in an Iranian setting. The few studies focused on some post reading activities such as reading aloud, and some others like role-play and poster making were nearly neglected. This study made use of the neglected ones and investigated their effects on improving reading ability of EFL learners.

The findings indicated that both activities, namely, role play and poster making were effective, but role play stood higher than poster design in terms of its impact on reading ability of the learners. Thus, it could be concluded that post reading activities can be useful and they bear such merits as helping students use their acquired knowledge in similar readings, helping them integrate their reading skills with the other language skills: listening, speaking and writing, helping them integrate with the foreign culture, making use of key words and structures to summarize the reading passage, extracting the main idea of a paragraph or a reading text, interpreting descriptions (outlining and summarizing), and making use of multiple classroom techniques for reading.

\section{References}

Adams, M. M. J. (1994). Beginning to read: Thinking and learning about print. Cambridge, MA: MIT Press.

Aduradola, R. R., \& Akeredolu-Ale, B. I. (2013). The power of student's involvement: Using posters as teaching tools in managing large classes. English for Specific Purposes World, 14(40), 1-20.

Ajideh, P. (2006). Schema-theory based considerations on pre-reading activities in ESP textbooks. Asian EFL Journal, 16, 1-19.

Alessi, S., \& Dwyer, A. (2008). Vocabulary assistance before and during reading. Reading in a Foreign Language, 20(2), 246-263.

Allan, D. (2004). Oxford Placement Test 2: Test pack. Oxford, England: Oxford University Press.

Al-Mansour, N. S., \& Al-Shorman, R. A. (2011). The effect of teacher's storytelling aloud on the reading comprehension of Saudi elementary stage students. Journal of King Saud University-Languages and Translation, 23(2), 69-76. https://doi.org/10.1016/j.jksult.2011.04.001

Atay, D., \& Kurt, G. (2006). Elementary school EFL learners' vocabulary learning: The effects of post-reading activities. Canadian Modern Language Review, 63(2), 255-273. https://doi.org/10.3138/cmlr.63.2.255

Bibi, K., Majoka, M. I., Mahmood, T., \& Tariq, M. A. (2015). Relationship of students' achievement level and effectiveness of role play method at secondary level. AYER, 1, 463-468.

Blanter, A. (2009). Role playing in education. Retrieved from http://www.blatner.com/adam/pdntbk/rlplayedu.htm

Brassell, D., \& Rasinski, T. V. (2008). Comprehension that works: Taking students beyond ordinary 
Effect of interactive post-reading tasks on reading comprehension of young adults pre-intermediate EFL learners understanding to deep comprehension. Huntington Beach, CA: Shell Education.

Dörnyei, Z., \& Ushioda, E. (2013). Teaching and researching: Motivation. London, the United Kingdom: Routledge.

Gorjian, B., Moosavinia, S. R., \& Jabripour, A. (2010). Dramatic performance in teaching drama in EFL contexts. TESL-EJ, 13(4), 1-13.

Gosling, P. J. (2012). Scientist's guide to poster presentations. Berlin, Germany: Springer Science \& Business Media.

Kodotchigova, M. A. (2001). Role play in teaching culture: Six quick steps for classroom (Master's Thesis). Tomsk State University, Russia.

Kowsary, M. A. (2013). The effect of teacher's reading aloud on Iranian EFL learners' reading comprehension (Master's Thesis). Hakim Sabzevari University.

Lee, L., \& Gundersen, E. (2001). Select readings: Pre-intermediate level. New York, NY: Oxford University Press.

Max, G. (2002). The poster in history. New York, NY: WW Norton \& Company.

Rayner, K., Foorman, B. R., Perfetti, C. A., Pesetsky, D., \& Seidenberg, M. S. (2001). How psychological science informs the teaching of reading. Psychological Science in the Public Interest, 2(2), 31-74.

Richards, J. C., \& Rodgers, T. S. (2014). Approaches and methods in language teaching. Cambridge, England: Cambridge University Press.

Richards, J. C., \& Schmidt, R. (2010). Longman dictionary of language teaching and applied linguistics (4th ed.). London, England: Routledge.

Schellin, K. (2006). Simulation, role play, and drama in a communicative classroom. Yamawaki Studies of Arts and Science, 44, 32-41.

Simpson, A. (2013). 9 great reasons to use posters in your language classroom. Retrieved from http://www.teachthemenglish.com/2013/11/29/9-great-reasons-to-use-posters-in-your-language-classroo $\underline{\mathrm{m} /}$

Tarpey, T. (2007). Language play: Implications for the second-language learner. Working Papers in TESOL \& Applied Linguistics, 7(2), 1-25.

Wolfe, A. B. (2015). Post-reading strategies. Retrieved from http://www.balancingthesword.com

Yusuf, H. O. (2015). Interactive activities and its impact on students' performance in reading comprehension in senior secondary schools in Kaduna, Nigeria. Procedia-Social and Behavioral Sciences, 174, 523-528. https://doi.org/10.1016/j.sbspro.2015.01.698 
Salavati, A., \& Tabatabaei, O. 